\title{
FAKTOR -FAKTOR YANG BERHUBUNGAN DENGAN KEJADIAN DIARE PADA ANAK DI WILAYAH KERJA PUSKESMAS ALALAK TENGAH KOTA BANJARMASIN
}

\author{
Related Factors With Diare Events On Children In The Work Of Puskesmas Alalak Tengah \\ Banjarmasin City
}

\author{
Eka Marliyanti, Akhmad Fauzan, Norfai \\ Fakultas Kesehatan Masyarakat UNISKA MAB Banjarmasin \\ Email : akhmadfauzan.fkmuniska@gmail.com
}

\begin{abstract}
Diarrhea is still a public health problem in developing countries such as Indonesia, diarrhea is the third cause of death at all ages. Diarrhea morbidity in 2010 had 411 patients per 1000 population. The study aimed to determine the factors associated with the incidence of diarrhea in children in the working area of the Alalak Tengah Health Center in Banjarmasin City. The research design used is cross-sectional. The independent variable in this study is nutritional status and behavior, while the dependent variable is the incidence of diarrhea. The population in this study were school-age children aged 7-12 years with a sample of 93 respondents who were taken using a random sampling technique. Data was collected by interviewing respondents and analysis used in two stages, namely univariate and bivariate with ChiSquare test. The results showed that nutritional status was not associated with diarrhea incidence pvalue $=0.073$ (p-value $>0.05$ ), and children's behavior was associated with diarrhea incidence $p$-value $=0.000$ (p-value <0.05). From the results of the study, it can be concluded that the high and low nutritional status of children does not affect the incidence of diarrhea and bad handwashing behavior of children can cause diarrhea. It is suggested to the puskesmas to further improve health promotion through counseling of schools about diarrhea and good and right-hand washing.
\end{abstract}

Keywords: Diarrhea, nutritional status, and behavior

\begin{abstract}
Abstrak
Penyakit diare masih merupakan masalah kesehatan masyarakat di Negara berkembang seperti di Indonesia, diare merupakan penyebab kematian nomor tiga pada semua usia. Angka kesakitan diare pada tahun 2010 ada 411 penderita per 1000 penduduk. Penelitian bertujuan untuk mengetahui faktor-faktor yang berhubungan dengan kejadian diare pada anak di wilayah kerja Puskesmas Alalak Tengah Kota Banjarmasin. Desain penelitian yang digunakan yaitu cross sectional. Variabel bebas dalam penelitian ini adalah status gizi dan perilaku, sedangkan variabel terikatnya adalah kejadian diare. Populasi dalam penelitian ini adalah anak usia sekolah yang berumur 7-12 tahun dengan sampel sebanyak 93 responden yang diambil dengan menggunakan teknik pengambilan sampel random sampling. Data dikumpulkan dengan wawancara terhadap responden dan analisis yang digunakan melalui dua tahap yaitu univariat dan bivariat dengan uji Chi Square. Hasil penelitian menunjukkan bahwa status gizi tidak berhubungan dengan kejadian diare $p$-value $=0,073$ ( $p$-value $>0,05)$, dan perilaku anak berhubungan dengan kejadian diare $p$-value $=0,000$ ( $p$-value $<0,05$ ). Dari hasil penelitian dapat disimpulkan bahwa tinggi rendahnya status gizi anak tidak berpengaruh terhadap kejadian diare dan perilaku mencuci tangan anak yang buruk dapat menyebabkan terjadinya penyakit diare. Disarankan kepada pihak puskesmas untuk lebih meningkatkan lagi promosi kesehatan melalui penyuluhan kesekolah tentang diare dan mencuci tangan yang baik dan benar.
\end{abstract}

Kata Kunci : Diare, status gizi dan perilaku 


\section{PENDAHULUAN}

Penyakit diare masih merupakan masalah kesehatan masyarakat di negara berkembang seperti di Indonesia, karena morbiditas dan mortalitasnya yang masih tinggi. Menurut data World Health Organization (WHO) sebagaimana dikatakan diare merupakan penyebab kematian nomor tiga pada semua usia. Angka kesakitan diare pada tahun 2010 berjumlah 411 penderita per 1000 penduduk. Sedangkan untuk angka kesakitan diare di Indonesia adalah sekitar 200-400 kejadian diare diantara 1000 penduduk setiap tahunnya. Kejadian diare di Indonesia berjumlah 60 juta pertahunnya dan 80\% adalah anak-anak (Kemenkes RI, 2011).

Hasil survei subdit diare, angka kesakitan penyakit diare semua golongan umur pada tahun 2006 sebesar 423 per 1000 penduduk, tahun 2010 dan 2011 sebesar 411 per 1000 penduduk. Angka kematian semua golongan umur 23,2 per 100.000 penduduk. Diare meupakan penyebab kematian no 4 $(13,2 \%)$ pada semua umur dalam kelompok penyakit menular (Dinas Kesehatan Kota Banjarmasin, 2016).

Jumlah anak yang ada di kelurahan Alalak Tengah sebanyak 1.471 anak. Jumlah anak laki-laki sebanyak 743 dan jumlah anak perempuan sebanyak 728 anak. Menurut informasi yang didapat temuan kasus diare pada anak sekolah dasar di Puskesmas Alalak Tengah Kota Banjarmasin pada tahun 2016 sebanyak 77 kasus, dan pada tahun 2017 sebanyak 85 kasus dimana kasus terbanyak terjadi pada anak laki-laki yaitu pada tahun 2016 jumlah penderita pada anak laki - laki sebanyak 46 orang dan pada anak perempuan sebanyak 31 orang sedangkan pada tahun 2017 jumlah anak laki - laki yang menderita diare berjumlah 48 orang dan pada anak perempuan berjumlah 37 anak (Puskesmas Alalak Tengah, 2017).

Berdasarkan data yang telah diuraikan diatas bahwa angka kejadian diare di wilayah kerja Puskesmas Alalak Tengah Kota Banjarmasin masih tinggi, maka perlu dilakukan penelitian tentang faktor-faktor yang berhubungan dengan kejadian diare pada anak usia yang nantinya berguna dalam penyusunan strategi penurunan kejadian diare berdasarkan sumber dana yang ada di wilayah kerja Puskesmas Alalak Tengah Kota Banjarmasin.

\section{BAHAN DAN METODE}

Penelitian ini merupakan suvei analitik dengan pendekatan cross sectional, yaitu variabel sebab akibat yang terjadi pada objek penelitian diukur atayu dikumpulkan secara simultan. Populasi pada penelitian ini yaitu anak usia sekolah umur (712 tahun) yang berjumlah 1.471 anak yang tinggal dalam wilayah kerja Puskesmas Alalak Tengah Kota Banjarmasin Tahun 2018. Teknik pengambilan sampel dengan cara simple random sampling berjumlah 93 sampel. Instrumen yang digunakan dalam penelitian ini adalah kuesioner. Analisis data yang digunakan adalah uji statistic Che Square dengan tingkat kepercayaan 95\%.

\section{HASIL DAN PEMBAHASAN}

\section{Analisis Univariat}

Hasil analisis univariat dalam penelitian ini terdiri dari kejadian diare, status gizi, dan perilaku dapat dilihat pada tabel 1. Hasil penelitian menunjukkan bahwa dari 93 responden penelitian kejadian diare pada anak terjadi sebanyak 50 orang (53.8\%). Dari 93 responden penelitian yang status gizi nya normal sebanyak 33 anak (39,8\%)dan status gizi sangat kurus sebanyak 14 anak (24,7\%). Dari 93 responden penelitian yang perilakunya kurang baik sebanyak 49 anak (52,7\%).

Tabel 1. Distribusi Frekuensi Berdasarkan Kejadian Diare, Status Gizi dan Perilaku Anak di Wilayah Kerja Puskesmas Alalak Tengah Kota Banjarmasin

\begin{tabular}{lcc}
\hline Vaiabel & $\mathbf{n}$ & $\mathbf{0}$ \\
\hline Kejadian Diare & & \\
Diare & 50 & 53,8 \\
Tidak Diare & 43 & 46,2 \\
\hline Status Gizi & & \\
Sangat Kurus & 23 & 24,7 \\
Kurus & 22 & 23,7 \\
Normal & 37 & 39,8 \\
Gemuk & 11 & 11,8 \\
\hline Perilaku Anak & & \\
Kurang Baik & 49 & 52,7 \\
Baik & 44 & 47,3 \\
\hline Jumlah & 93 & 100 \\
\hline
\end{tabular}

\section{Analisis Bivariat}

Analisis hubungan antara status gizi dan perilaku anak dengan kejadian diare pada anak di wilayah kerja Puskesmas Alalak Tengah Kota Banjarmasin dapat dilihat pada tabel 2 . 
Tabel 2. Faktor-Faktor yang Berhubungan dengan Kejadian Diare pada Anak di Wilayah Kerja Puskesmas Alalak Tengah Kota Banjarmasin

\begin{tabular}{|c|c|c|c|c|c|c|c|}
\hline \multirow{3}{*}{ Variabel } & \multicolumn{4}{|c|}{ Kejadian Diare } & \multirow{2}{*}{\multicolumn{2}{|c|}{ Jumlah }} & \multirow{3}{*}{ p-value } \\
\hline & \multicolumn{2}{|c|}{ Diare } & \multicolumn{2}{|c|}{ Tidak Diare } & & & \\
\hline & $\mathbf{n}$ & $\%$ & $\mathbf{n}$ & $\%$ & $\mathbf{n}$ & $\%$ & \\
\hline Status Gizi & & & & & & & \\
\hline Sangat Kurus & 12 & 52,2 & 11 & 47,8 & 23 & 100 & \multirow{4}{*}{0,073} \\
\hline Kurus & 14 & 63,6 & 8 & 36,4 & 22 & 100 & \\
\hline Normal & 22 & 59,5 & 15 & 40,5 & 37 & 100 & \\
\hline Gemuk & 2 & 18,2 & 9 & 81,8 & 11 & 100 & \\
\hline \multicolumn{8}{|l|}{ Perilaku Anak } \\
\hline Kurang Baik & 44 & 89,8 & 5 & 10,2 & 49 & 100 & \multirow[b]{2}{*}{0,000} \\
\hline Baik & 6 & 13,6 & 38 & 86,4 & 44 & 100 & \\
\hline Jumlah & 50 & 53,8 & 43 & 46,2 & 93 & 100 & \\
\hline
\end{tabular}

Hubungan Status Gizi dengan Kejadian Diare pada Anak di Wilayah Kerja Puskesmas Alalak Tengan Kota Banjarmasin

Pada tabel 2 dapat dilihat bahwa dari total sampel 93 responden, status gizi dengan kategori normal terdapat 22 orang yang pernah mengalami diare dan 15 responden yang tidak mengalami diare, responden dengan kategori sangat kurusyang mengalami diare sebanyak 12 responden sedangkan yang tidak mengalami diare sebanyak 11 responden, responden dengan kategori kurus ternyata tedapat 14 responden yang pernah mengalami diare, sedangkan responden yang tidak mengalami diare sebanyak 8 responden, dan dari responden dengan kategori gemuk terdapat 2 orang yang pernah mengalami diare sedangkan yang tidak mengalami diare sebanyak 9 responden.

Berdasarkan hasil uji statistik menggunakan chi-square antara variabel status gizi dengan kejadian diare didapatkan hasil p-value 0,073 dimana $p$-value > a $(0,05)$ yang artinya tidak ada hubungan antara status gizi dengan kejadian diare pada anak. Dengan demikian dapat disimpulkan bahwa status gizi anak dengan kategori normal lebih banyak dibandingkan dengan gemuk,sangat kurus, dan kurus. Tidak ada hubungan yang signifikan antara status gizi dengan kejadian diare pada anak, dari hasil penelitian diketahui bahwa status gizi anak tidak berpengaruh terhadap kejadian diare, meskipun kategori anak.

Kurus bukan berarti anak tersebut sedang diare dan begitu pula sebaliknya anak dengan kategori normal atau gemuk juga bisa terkena diare dan diare banyak terjadi pada anak laki-laki. Banyak faktor langsung maupun tidak langsung yang mempengaruhi status gizi seseorang. Faktor yang behubungan langsung yaitu makanan dan penyakit baik asupan makanan dan penyakit sama kuatnya dalam mempengaruhi status gizi anak. Sedangkan faktor tidak langsung yang menyebabkan gizi kurang yaitu ketahanan pangan keluarga yang kurang memadai baik jumlah maupun mutu, kemiskinan kadang menjadikan hambatan dalam penyediaan pangan bagi keluarga, pola pengasuhan anak kurang memadai yang meliputi waktu, perhatian dan dukungan untuk tumbuh dengan baik, pelayanan kesehatan dan lingkungan kurang memadai yang meliputi penyediaan air bersih. Oleh sebab, itu masukan makanan atau zat gizi harus diperhatikan agar tidak terjadi penurunan metabolisme di dalam tubuh sehingga menyebabkan diare.

Hasil penelitian ini sejalan dengan penelitian yang dilakukan oleh Mursilah (2010) menyatakan bahwa tidak terdapat hubungan antara keadaan status gizi dengan frekuensi kejadian diare pada balita di Kelurahan Pisangan Kecamatan Ciputat Timur dengan $p$-value $(0,191)$ ( $p$-value $>0,05)$.

Hubungan Perilaku Anak dengan Kejadian Diare pada Anak di Wilayah Kerja Puskesmas Alalak Tengan Kota Banjarmasin

Dari hasil penelitian dari 93 responden perilaku anak dengan kategori kurang baik terdapat 44 responden yang pernah mengalami diare, sedangkan responden yang tidak mengalami diare sebanyak 4 responden dan responden dengan kategori baik yang pernah mengalami diare 
sebanyak 6 responden sedangkan yang tidak mengalami diare sebanyak 38 responden. Berdasarkan uji hipotesis dengan menggunakan uji chi-square antara variabel perilaku anak dengan kejadian diare diperoleh $p$-value $(0,000)$ dimana nilai $p$-value $<a(0,05)$ yang artinya ada hubungan yang signifikan antara perilaku anak dengan kejadian diare pada anak.

Hasil penelitian ini menunjukkan bahwa anak yang perilakunya dalam kategori kurang baik lebih banyak dibandingkan dengan kategori baik. Ini didapat dari hasil jawaban pertanyaan kuesioner mengenai perilaku mencuci tangan anak dalam kehidupan sehari-hari yang menyangkut perilaku mencuci tangan setelah makan dan sebelum makan, perilaku mencuci tangan setelah buang air besar dan kecil, perilaku mencuci tangan setelah membuang sampah dan perilaku mencuci tangan setelah memegang hewan karena mengetahui bahwa penyakit diare bisa terjadi melalui perilaku mencuci tangan yang kurang bersih. Perilaku mencuci tangan sangat penting untuk dilakukan dalam kegiatan sehari-hari untuk mencegah terjadinya penyakit diare.

Dari hasil penelitian yang didapat ada anak yang berperilaku baik akan tetapi tetap pernah terkena diare, dari hasil jawaban kuesioner dapat disimpulkan bahwa diare terjadi akibat banyak anakanak menjawab pertanyaan tidak mencuci tangan sebelum makan jajanan dan juga setelah memegang hewan.

Perilaku cuci tangan yang buruk berhubungan erat dengan peningkatan kejadian diare dan penyakit yang lain. Perilaku cuci tangan yang baik dapat menghindarkan diri dari diare. Apabila kita selalu mencuci tangan, kondisi tangan kita selalu bersih sehingga dapat melakukan aktivitas terutama makan tangan yang kita gunakan selalu bersih sehingga tidak ada kuman yang masuk kedalam tubuh. Cuci tangan pakai sabun adalah salah satu tindakan sanitasi dengan membersihkan tangan dan jari jemari menggunakan air dan sabun oleh manusia untuk menjadi bersih dan memutuskan mata rantai kuman. Mencuci tangan dengan air saja tidak cukup. Penggunaan sabun selain membantu singkatnya waktu cuci tangan, dengan menggosok jemari dengan sabun menghilangkan kuman yang tidak tampak minyak atau lemak atau kotoran di permukaan kulit, serta meninggalkan bau wangi.
Perpaduan kebersihan dan bau wangi dan perasaan segar merupakan hal positif yang diperoleh setelah menggunakan sabun (Depkes RI, 2010).

Hasil penelitian ini sejalan dengan penelitian yang dilakukan oleh Fatmawati, dkk (2016) dengan judul faktor yang mempengaruhi kejadian diare pada anak usia 3-6 tahun di TK Raudhatul Athfal Alauddin Makassar menyatakan bahwa kejadian diare berdasarkan perilaku cuci tangan responden yang terdiri dari perilaku cuci tangan kategori baik dan tidak baik menunjukkan bahwa sebanyak 10 orang $(47,6 \%)$ responden yang memiliki perilaku cuci tangan yang tidak baik mengalami diare dan 1 orang $(2,4 \%)$ responden tidak mengalami diare. Responden yang memiliki perilaku cuci tangan yang baik yang mengalami diare sebanyak 11 orang $(52,4 \%)$ dan tidak mengalami diare sebanyak 40 orang $(97,6 \%)$. Hasil uji Fisher exact diperoleh nilai $\mathrm{p}$ $=0,000(\mathrm{p}<0,001)$ maka dapat disimpulkan bahwa ada hubungan yang signifikan antara perilaku cuci tangan dengan kejadian diare. Hasil analisis diperoleh pula nilai $\mathrm{OR}=36,364$ artinya : responden yang memiliki perilaku cuci tangan yang tidak baik mempunya peluang 36,364 kali mengalami diare.

\section{KESIMPULAN DAN SARAN}

Berdasarkan penelitian didapatkan kesimpulan bahwa status gizi anak sebagian besar masuk dalam kategori normal yaitu sebanyak 37 anak $(39,8 \%)$. Perilaku anak sebagian besar masuk dalam kategori kurang baik yaitu sebanyak 49 anak $(52,7 \%)$. Secara statistik tidak adanya hubungan yang bermakna antara status gizi dengan kejadian diare pada anak di wilayah kerja Puskesmas Alalak Tengah kota Banjarmasin dan adanya hubungan yang bermakna antara perilaku anak dengan kejadian diare pada anak di wilayah kerja Puskesmas Alalak Tengah Kota Banjarmasin. Perlunya peningkatan upaya penyuluhan kepada masyarakat terutama pada anak-anak usia sekolah tentang pentingnya perawatan kesehatan dan perilaku mencuci tangan yang baik dan benar guna pencegahan terjadinya penyakit diare.

\section{DAFTAR PUSTAKA}

Depkes, RI., 2010. Pedoman Pemberantasan Penyakit Diare. Jakarta: Depkes RI. 
Dinas Kesehatan Kota Banjarmasin, 2016. Profil Dinas Kesehatan Kota Banjarmasin. Banjarmasin: Dinkes Kota Banjarmasin.

Puskesmas Alalak Tengah, 2017. Profil Puskesmas Alalak Tengah. Banjarmasin : Puskesmas Alalak Tengah.

Kementrian Kesehatan, RI., 2011. Buletin Jendela Data dan Informasi Kesehatan Volume 2 Triwulan 2, Jakarta: Kemenkes RI.

Mursilah, Hilyah., 2010. Hubungan Status Gizi dengan Frekuensi Kejadian Diare pada Balita di Kelurahan Pisangan Bulan Agustus 2010. Skripsi. Program Studi Pendidikan Dokter, Fakultas Kedokteran dan Ilmu Kesehatan, Universitas Islam Negeri Syarif Hidayatullah Jakarta. [Online]. http:/ / repository.uinjkt.ac.id/dspace/bitstrea m/123456789/26359/1/Hilyah\%20Mursilahfkik.pdf. [Diakses pada tanggal 17 Juli 2018].

Fatmawati, Arbianingsih, Musdalifah., 2016. Faktor yang mempengaruhi kejadian diare pada anak usia 3-6 tahun di TK Raudhatul Athfal Alauddin Makassar. Vol. 1, No. 1. [Online]. http:/ journal.uinalauddin.ac.id/index.php/join/article/view/3 509/3281. [Diakses pada tanggal 17 Juli 2018]. 